\title{
The Role of Cognitive Empathy on Adolescents' Phubbing During Pandemic Covid-19
}

\section{Charyna Ayu Rizkyanti, Nabilah Edyta, Nefira Dewi Fitrusti}

\author{
Universitas Pancasila, Jakarta, Indonesia \\ Email Address: charyna@univpancasila.ac.id
}

Submitted : 29-06-2021, Revised : 26-08-2021, Accepted : 17-11-2021

\begin{abstract}
During the Covid-19 pandemic, various activities, including the learning process, have shifted to digital platforms. This is a serious concern because teenagers interact more easily with smartphones than pay attention to other people during social interactions, which is called "phubbing". The purpose of this study was to examine the role of cognitive empathy in phubbing among adolescents who use social media. By using the volunteer sampling (opt-in) panel technique, a total of 398 respondents (aged 16-21) were taken part in this study. Respondents filled out two instruments, namely the Phubbing Scale (10 items), the Basic Empathy Scale (9 items). There is an effect of cognitive empathy on phubbing in adolescent social media users, with a contribution value of $38 \%$. The results showed there was a gender difference, with girls reporting higher levels of phubbing and cognitive empathy than boys. This study is the first to provide empirical evidence on the role of cognitive empathy for phubbing on social media among adolescents. This highlights the importance of efforts to indulge our culture as our national identity to stop phubbing becoming the new norm in society, including the younger generation. Keywords: Adolescent; Cognitive empathy; Phubbing; Social media
\end{abstract}

\section{Introduction}

In today's digital era, interactions are no longer face-to-face. The existence of a smartphone replace direct interaction and allow people to interact by sending messages, video call, etc in a short time. Moreover, the pandemic Covid-19 which has been going on for more than a year cause people to do activities remotely from home, including the learning process that has been conducted online. As for the impact of this situation, people are increasingly attached to their device, including the smartphone to stay connected (Ratan et al., 2021).

In describing the interaction among people through their smartphones, there is a phenomenon that shows how people often ignore others with whom they are physically interacting. In 2012, the Macquarie Dictionary campaign invited several writers, lexicographers, and poets to create new words to describe an individual's excessive behaviour or action which is ignoring their social environment due to focusing on their phone only (Ugur \& Koc, 2015). It is considered as an impolite behaviour, yet, the term 'Phubbing' appeared.

Phubbing stands for "phone snubbing", can be described as an individual looking at his/her smartphone during a conversation with other individuals, dealing with the mobile phone and escaping from interpersonal communication (Karadağ et al., 2015). Since phubbing involves individuals with smartphones in their social environment, it is also considered as a disrespectful attitude towards the person or persons with whom one is in communication, disregarding them, and preferring virtual environments to real-life ones. This behaviour seems to have become normative in daily communication nowadays (Chotpitayasunondh \& Douglas, 2018).

According to Karadağ et al., (2015), there are two factors of Phubbing, (i) communication disturbance which shows how often individuals disturb their face-to-face 
communication by using their mobile phones, and (ii) phone obsession which reflects the need for their mobile phone in a social setting that does not involve face-to-face interaction. In social interaction, a person who starts phubbing his or her companion(s) can be called a "phubber", while a person who is a recipient of phubbing behaviour can be defined as a “phubbed”(Chotpitayasunondh \& Douglas, 2018).

Phubbing consists of multi-dimensional structure, i.e., (i) mobile phone addiction, (ii) internet addiction, (iii) social media addiction, and (iv) game addiction (Karadağ et al., 2015). In adolescence, most of their time online is spent on social media (Ahn \& Jung, 2016; Barry et al., 2017; Kuss \& Griffiths, 2017). Indonesia is on the 5th rank with the number of social media users increasing by 10 million between 2020 and 2021 (Kemp, 2021), where adolescents were found to be the highest of social media usage with a percentage of 91\% (APJII, 2018). Thus, social media has a significant platform among the addiction objects of smartphones (Kwon et al., 2013). While adolescents show an effort to maintain their presence in social media to live their real lives, but at the same time, they are degrading their activities in real life. It illustrates the functioning of phubbing, were adolescents' efforts to announce their presence in the real world through social media by their smartphones (Karadağ et al., 2015).

Phubbing might be considered disrespectful behaviour towards others (Karadağ et al., 2015). It may result in both direct and indirect negative impacts on relationship satisfaction (Roberts \& David, 2016), including a problematic behaviour that could harm both phubbers and those being phubbed (Chotpitayasunondh \& Douglas, 2016). Compare to youth people, older adults appeared to be generally less lenient toward phubbing behaviour. It reveals the evidenced by $50 \%$ of younger adults believing it was acceptable to use a smartphone in a restaurant compared to only $26 \%$ of older adults who held the same view (Ranie \& Zickuhr, 2015). Older adult participants (the mean age was 71 years) found phubbing as disruptive to communication quality, offensive, breached social etiquette, and described fewer situations where phubbing was acceptable (Kadylak et al., 2018). Therefore, the factors that may lead to phubbing should be further examined.

In a social setting, people would rather communicate via text instead of talking face-to-face by looking at his/her phone instead of paying attention to others (Ugur \& Koc, 2015). Therefore, it has been argued that lack of empathy is an antecedent of addictive behaviour to smartphone use (Misra et al., 2016; Melchers et al., 2015; Lachmann et al., 2018). Konrath et al., (2011) emphasizes that the declines in empathy could be related to people spending time online and engaging in superficial interactions with others, further, Small and Vorgan (2008) revealed that being online reduces an individual's capacity for empathy. By contrast, the research results of (Carrier et al., 2015),indicated spending time online does not reduce individual empathy in the real world since people may get social support through a social media environment which produces the same strong sense of social support that empathy does in the real world.

Empathy is defined as the individual's ability to understand the condition and feel the emotional state of others (Jolliffe \& Farrington, 2006). This definition was brought from Cohen and Strayer (1996) who explained empathy as an affective trait and a cognitive ability as well. Based on the definition, empathy consists of two dimensions, affective empathy as the ability to feel the emotional status of others and cognitive empathy as the ability to understand 
the perspective/point of view of others. Theoretically, empathy is known to appear in stage four (empathy for another life condition) in early childhood up to elementary school. In contrast to affective empathy that appears very early in life, cognitive empathy follows a slower development (Decety \& Meyer, 2008), in the adolescence phase. The existence of empathy allows individuals to understand what others want, predict behaviour and experience the emotions that are triggered by others' emotions (Baron-cohen \& Wheelwright, 2004). It was found that affective empathy is initiated through direct, face-to-face contact (Preston \& Waal, 2002), cognitive empathy can occur through media such as books, stories, even through social media platforms.

Since social media has become a continuous, integral part of the individual, it appears that nowadays individuals perceive phubbing as something usual with the social norms, particularly those who are closest to them such as friends, partners, and family compared to strangers (Al-Saggaf \& Macculloch, 2019). Moreover, people would rather communicate via text instead of talking face-to-face by looking at his/her phone instead of paying attention towards others in a social setting (Ugur \& Koc, 2015). Individuals feel comfortable and do not worry whether their behaviour will be judged negatively (Bulantika \& Sari, 2019). Yet, people tend to adopt such norms quickly since they assume others will think and do the same the way they do (Thahir et al., 2021). Therefore, individuals with high cognitive empathy are better able to understand, read, and imagine people's points of view, perspectives, or emotions (cognitive empathy), thus, it will be likely more related to ignoring people who talk to them, which refers to phubbing behaviour.

Although several previous studies have investigated empathy and phubbing, however, there have been no studies attempting to ascertain the role of each empathy dimension in phubbing behaviour. It is considered important since prior studies found different effects and consequences based on each empathy dimension towards behaviour. Thus, this research particularly assesses to what extent the cognitive dimension of empathy will affect adolescents to phub through social media. It takes into account that cognitive empathy may appear without face-to-face interaction, in other words, online communication is a suitable platform for individuals to experience phubbing. Therefore, this study aims to determine empirically the effect of cognitive empathy on phubbing in adolescent social media users.

\section{Methods}

This study used a quantitative approach based on a cross-sectional design. This design was considered suitable since the aim of this study was to determine the prevalence of a phenomenon, problem, attitude or problem situation by taking part of the population. Population and sample of 398 social media users, such as Instagram, Facebook, Twitter, TikTok, Whatsapp, and Line, aged between 16-21 years were involved in this study. The number of participants was calculated by using the GPower 3.1 statistical test that has an effect size of 0.3 on the choice of the normal correlation model. The data collection technique used in this study is distributed through online questionnaires that can be completed by participants using the internet. The online questionnaire will be distributed through social media, making it easier for participants to access and fill out the questionnaire. After participants have completed the questionnaire, then participants are asked to press the submit button on the available page, yet the responses given can be recorded (Shaughnessy, Zechmeister \& Zechmeister, 2012). The Phubbing Scale (TPS) (Karadağ et al., 2015) comprises 10 items on a 4-point Likert scale from 
never to always, with two factors (five items for each factor): communication disturbances (e.g., My eyes start wandering on my phone when I'm together with others) and phone obsession (e.g., When I wake up in the morning, I first check the messages on my phone). The item reliability was found .98. Basic Empathy Scale (BES) was used to measure empathy levels (Jolliffe \& Farrington, 2006). This self-report scale, designed for adolescents, is consisted of 9 items that measure cognitive empathy. The cognitive aspect of empathy relates to a person's ability to recognize and comprehend the emotions of another person. An example item from the cognitive aspect of empathy is "I find it hard to know when my friends are frightened" (reverse coded). Items on the scale were rated on a 4-point, Likert-type rating scale, with 1 being "'Strongly Disagree," 4 being "Strongly Agree." The item reliability was found .97. The instrument validity was carried out using Rasch Model Winstep software. The simple regression was used to determine the effect of cognitive empathy on phubbing in late adolescents who are actively using social media. The analysis was carried out using IBM SPSS Statistics 22 software.

\section{Results and Discussion}

There are 398 respondents involved in this study. The majority of respondents are 21 years old. Domicile Bogor dominates, with 3-4 social media being the most used and most frequently used. The maximum duration of social media usage is more than 8 hours.

Tabel 1.

Respondents description

\begin{tabular}{lll}
\hline & Frequency & $\mathbf{( \% )}$ \\
\hline Age & 9 & \\
16 year old & 37 & 2,3 \\
17 year old & 61 & 9,3 \\
18 year old & 54 & 15,3 \\
19 year old & 69 & 14,6 \\
20 year old & 168 & 42,3 \\
21 year old & & \\
Area & 108 & 27,1 \\
Jakarta & 121 & 30,4 \\
Bogor & 70 & 17,6 \\
Depok & 45 & 11,3 \\
Tangerang & 54 & 13,6 \\
Bekasi & & \\
A number of social media & 102 & 25,6 \\
1-2 & 234 & 58,8 \\
3-4 & 62 & 15,6 \\
5-6 & & \\
Duration of social media usage & & \\
<1 hours & 14 & 3,5 \\
>1-2 hours & 44 & 11,1 \\
>2-3 hours & 47 & 11,8 \\
>3-4 hours & 57 & 14,3 \\
>4-5 jam & 47 & 11,8 \\
>5-6 hours & 46 & 11,6
\end{tabular}




\begin{tabular}{lll}
$>6-7$ hours & 37 & 9,3 \\
$>8$ hours & 106 & 26,6 \\
\hline
\end{tabular}

Table 2.

Pearson correlation test

\begin{tabular}{llll}
\hline Model & R & R Square & Sig. \\
\hline Cognitive empathy & 0,195 & 0,38 & 0,000
\end{tabular}

Table 2 shows cognitive empathy significantly predicted phubbing $38 \%$ (R Square $=$ $0.38 \times 100 \%$, the value of sig. $0.000<0.05$. The table reveals cognitive empathy and phubbing were positively related $(\mathrm{R}=0.195)$. It shows the higher the cognitive empathy, the higher the phubbing in adolescents who use social media.

Table 3.

Simple regression between cognitive empathy and phubbing

\begin{tabular}{lllllll}
\hline Model & \multicolumn{2}{l}{$\begin{array}{l}\text { Unstandardized } \\
\text { Coefficients }\end{array}$} & $\begin{array}{l}\text { Standardized } \\
\text { Coefficients }\end{array}$ & Sig. & Tolerance & VIF \\
\hline & B & Std. Error & Beta & & & \\
\hline $\begin{array}{l}\text { Cognitive } \\
\text { Empathy }\end{array}$ & 0,470 & 0,119 & 0,195 & 0,000 & 1,000 & 1,000 \\
\hline
\end{tabular}

In table 3 , the value of sig. cognitive empathy variable $=0.000<0.05$, means cognitive empathy has a positive and significant effect on phubbing. It shows the higher the cognitive empathy, the higher the phubbing in adolescents who use social media.

Table 4.

T-test for phubbing by gender

\begin{tabular}{cccc}
\hline Gender & Mean & $\mathbf{t}$ & Sig. \\
\hline Male & 0,1965 & $-2,527$ & 0,012 \\
\hline Female & 0,5555 & $-2,669$ & 0,008 \\
\hline
\end{tabular}

Based on Table 4, it shows that the calculation results of the Independent Sample T-test show the value of Sig. $<0.05$. It means there is a significant difference in phubbing adolescent social media users by gender. The result depicts female tends to do phubbing $(\mathrm{M}=0.5555)$ compared to the male $(\mathrm{M}=0.1965)$.

Table 5.

T-test for cognitive empathy by gender

\begin{tabular}{llll}
\hline Gender & Mean & t & Sig. \\
\hline Male & 0,0632 & $-6,342$ & 0,000 \\
\hline Female & 0,4225 & $-6,474$ & 0,000 \\
\hline
\end{tabular}

Based on Table 5, the results of the Independent Sample T-test show the value of Sig. $<0.05$, which means that there is a significant difference in the cognitive empathy among 
adolescent social media users based on gender. It shows female tends to be higher $(\mathrm{M}=0.4225)$ compared to the male $(\mathrm{M}=0.0632)$ in cognitive empathy,

The results of this study show that cognitive empathy and phubbing were positively correlated $(\mathrm{R}=0.195)$. It shows the better adolescents comprehension, understanding, and prediction of others' mental states, the more they are ignoring people during a face-to-face conversation due to social media engagement. The value of the contribution of cognitive empathy to phubbing is $38 \%$. Indeed, this result cannot be separated from the current state of the COVID-19 pandemic. During the Covid-19 pandemic, social media remained critical to information access and social interaction. The more critical aspect, however, is understanding its application in online learning to meet students' learning needs during school closures due to the Covid-19 pandemic (Jogezai et al., 2021).

According to the simulation theory, individuals use cognitive ability to simulate actions (Adams, 2001), where it provides us with experiential access to other minds, to mirror, mimic, and simulate the actions and emotional states of other (Zahavi, 2008). Adolescents with high cognitive empathy show their imaginative apprehension of another's a mental state. As said previously, cognitive empathy can occur through media such as books, stories, and also social media platforms. When adolescents are preoccupied with their smartphones, they drown in stories that serve detailed moment-by-moment of various events through social media. Therefore, cognitive empathy is highly related to phubbing behaviour.

Adolescents with high cognitive empathy are better able to understand the point of view, read other people's perspectives, and identify the emotions of others (Caravita et al., 2009) which is related to phubbing. Phubbing behaviour is also known to differ from one group to another. This condition is closely related to prior research which suggests that the impact of phubbing varies depending on the relationship closeness between dyads. It appears that phubbing impacts those with whom the phubber has a closer relationship than those with whom the phubber has a distant relationship (Al-Saggaf \& Macculloch, 2019; Misra et al., 2016). Based on those previous results, adolescents who do phubbing are likely good at predicting how someone will feel and act since they know that people will not easily judge what they are doing since phubbing is considered a common thing nowadays.

Both phubbing and cognitive empathy among social media users based on gender found females tended to be higher compared to males. While prior studies have not been widely researched phubbing across sex groups (T'ng et al., 2018), nonetheless, research about Social Network Site users shows that girls are more interested in the relational aspects of media due to it is more central to girls' social lives, such as maintaining friendships (Espinoza \& Juvonen, 2011). Meanwhile, the results of cognitive empathy are in line with most previous research which empathy in females (both affective and cognitive) is higher than empathy in male (Jolliffe \& Farrington, 2006). Gender differences in empathy can be explained by the different social roles that men and women are assigned in society. Females are traditionally expected to be highly emotional and caring, whereas males are frequently depicted as being less emotional and stronger in times of weakness (Eisenberg, et al., 1992; Spinrad et al., 1999). As a result, girls have a broader range of emotions than boys. Yet, the dynamics of the highs and lows of empathy have varied when associated with other variables, for example when the research was conducted on the role of bullying (perpetrators, victims, passive observers, etc.). Therefore, research on gender differences in empathy is still being carried out until now. 
However, the role of cognitive empathy for phubbing needs to be considered because the ability to understand other people's points of view can have a negative impact, one of them is called Phubbing. The existence of the ability to imagine what other people think or this cognitive empathy can be used as a tool in attacking/intimidating others. As previously explained, in contrast to affective empathy which is known to motivate prosocial behaviour and reduce aggressive behaviour, this cognitive empathy can be exploited by bullies (Jolliffe \& Farrington, 2006). For example in the case of bullying, individuals with high cognitive empathy can use their ability to intimidate and invite others to engage in the act. Therefore, it is very important for adolescents who, according to Piaget's theory of cognitive development (Sari et al., 2020), enter the formal operational phase, this cognitive empathy will also develop perfectly at that stage. Thus, it is very important for parents, schools, and the surrounding environment to show concern for youth activities in cyberspace so as not to fall into phubbing by developing both affective and cognitive empathy of their adolescents.

\section{Conclusions and Suggestions}

This study shows the ability to understand other people's points of view or cognitive empathy plays a role in the phubbing behaviour among adolescents who use social media in this COVID-19 pandemic situation. This finding illustrates that the state of the COVID-19 pandemic has an impact on how cognitive empathy contributes to phubbing behaviour. This result highlights the importance of the attempt to indulge our culture as our national identity to stop phubbing being a new norm in society, including adolescents. Therefore, research about empathy and phubbing still need to be investigated due to inconsistent findings. Further researchers may include mediator variables such as the conflict between adolescents and parents, parenting or attachment patterns, and group pressure on adolescents. Since the number of female respondents is much larger than that of male respondents, the next researcher can pay more attention to more effective ways to attract male respondents so that the number is proportional.

\section{References}

Adams, F. (2001). Empathy, neural imaging and the theory versus simulation debate. Mind and Language, 16(4), 368-392. https://doi.org/10.1111/1468-0017.00176

Ahn, J., \& Jung, Y. (2016). The common sense of dependence on smartphone: A comparison between digital natives and digital immigrants. New Media and Society, 18(7), 12361256. https://doi.org/10.1177/1461444814554902

Al-Saggaf, Y., \& Macculloch, R. (2019). Phubbing and Social Relationships: Results from an Australian Sample. Journal of Relationships Research. https://doi.org/10.1017/jrr.2019.9

Baron-cohen, S., \& Wheelwright, S. (2004). The empathy quotient: an investigation of adults with Aspeger syndrome or high functioning autism, and normal sex differences. Journal of Autism and Developmental Disorders, 34(2), 163-175. https://doi.org/10.1023/B:JADD.0000022607.19833.00

Barry, C. T., Sidoti, C. L., Briggs, S. M., Reiter, S. R., \& Lindsey, R. A. (2017). Adolescent social media use and mental health from adolescent and parent perspectives. Journal of Adolescence, 61, 1-11. https://doi.org/10.1016/j.adolescence.2017.08.005 
Bulantika, S. Z., \& Sari, P. (2019). The Effectiveness of Assertive Training Techniques and Thought-Stopping Techniques to Increase Student Assertiveness Ability. Biblio Couns: Jurnal Kajian Konseling Dan Pendidikan, 2(3), 109-116.

Caravita, S. C. S., Di Blasio, P., \& Salmivalli, C. (2009). Unique and interactive effects of empathy and social status on involvement in bullying. Social Development, 18(1), 140163. https://doi.org/10.1111/j.1467-9507.2008.00465.x

Carrier, L. M., Spradlin, A., Bunce, J. P., \& Rosen, L. D. (2015). Virtual empathy: Positive and negative impacts of going online upon empathy in young adults. Computers in Human Behavior, 52, 39-48. https://doi.org/10.1016/j.chb.2015.05.026

Chotpitayasunondh, V., \& Douglas, K. M. (2016). How "phubbing" becomes the norm: The antecedents and consequences of snubbing via smartphone. Computers in Human Behavior, 63, 9-18. https://doi.org/10.1016/j.chb.2016.05.018

Chotpitayasunondh, V., \& Douglas, K. M. (2018). The effects of "phubbing" on social interaction. Journal of Applied Social Psychology, 48(6), 304-316. https://doi.org/10.1111/jasp.12506

Decety, J., \& Meyer, M. (2008). From emotion resonance to empathic understanding: A social developmental neuroscience account. Development and Psychopathology, 20(4), 10531080. https://doi.org/10.1017/S0954579408000503

Espinoza, G., \& Juvonen, J. (2011). The pervasiveness, connectedness, and intrusiveness of social network site use among young adolescents. Cyberpsychology, Behavior, and Social Networking, 14(12), 705-709. https://doi.org/10.1089/cyber.2010.0492

Jogezai, N. A., Baloch, F. A., Jaffar, M., Shah, T., Khilji, G. K., \& Bashir, S. (2021). Teachers' attitudes towards social media (SM) use in online learning amid the COVID-19 pandemic: the effects of SM use by teachers and religious scholars during physical distancing. Heliyon, 7(4), e06781. https://doi.org/10.1016/j.heliyon.2021.e06781

Jolliffe, D., \& Farrington, D. P. (2006). Development and validation of the Basic Empathy Scale. Journal of Adolescence, 29(4), 589-611. https://doi.org/10.1016/j.adolescence.2005.08.010

Kadylak, T., Makki, T. W., Francis, J., Cotten, S. R., Rikard, R. V., \& Sah, Y. J. (2018). Disrupted copresence: Older adults' views on mobile phone use during face-to-face interactions. Mobile Media and Communication, 6(3), 331-349. https://doi.org/10.1177/2050157918758129

Karadağ, E., Tosuntaş, Ş. B., Erzen, E., Duru, P., Bostan, N., Şahin, B. M., Çulha, I., \& Babadağ, B. (2015). Determinants of phubbing, which is the sum of many virtual addictions: A structural equation model. Journal of Behavioral Addictions, 4(2), 60-74. https://doi.org/10.1556/2006.4.2015.005

Konrath, S. H., O’Brien, E. H., \& Hsing, C. (2011). Changes in dispositional empathy in American college students over time: A meta-analysis. Personality and Social Psychology Review, 15(2), 180-198. https://doi.org/10.1177/1088868310377395

Kuss, D. J., \& Griffiths, M. D. (2017). Social networking sites and addiction: Ten lessons learned. International Journal of Environmental Research and Public Health, 14(3). 
https://doi.org/10.3390/ijerph14030311

Kwon, M., Lee, J. Y., Won, W. Y., Park, J. W., Min, J. A., Hahn, C., Gu, X., Choi, J. H., \& Kim, D. J. (2013). Development and Validation of a Smartphone Addiction Scale (SAS). PLoS ONE, 8(2). https://doi.org/10.1371/journal.pone.0056936

Lachmann, B., Sindermann, C., Sariyska, R. Y., Luo, R., Melchers, M. C., Becker, B., Cooper, A. J., \& Montag, C. (2018). The role of empathy and life satisfaction in internet and smartphone use disorder. Frontiers in Psychology, 9(MAR), 1-11. https://doi.org/10.3389/fpsyg.2018.00398

Melchers, M., Li, M., Chen, Y., Zhang, W., \& Montag, C. (2015). Low empathy is associated with problematic use of the Internet: Empirical evidence from China and Germany. Asian Journal of Psychiatry, 17, 56-60. https://doi.org/10.1016/j.ajp.2015.06.019

Misra, S., Cheng, L., Genevie, J., \& Yuan, M. (2016). The iPhone Effect: The Quality of InPerson Social Interactions in the Presence of Mobile Devices. Environment and Behavior, 48(2), 275-298. https://doi.org/10.1177/0013916514539755

Preston, S. D., \& Waal, F. B. M. De. (2002). Preston \& deWaal, 2002. Behavioural and Brain Sciences, 25, 1-72.

Ratan, Z. A., Zaman, S. Bin, Islam, S. M. S., \& Hosseinzadeh, H. (2021). Smartphone overuse: A hidden crisis in COVID-19. Health Policy and Technology, 10(1), 21-22. https://doi.org/10.1016/j.hlpt.2021.01.002

Roberts, J. A., \& David, M. E. (2016). My life has become a major distraction from my cell phone: Partner phubbing and relationship satisfaction among romantic partners. Computers in Human Behavior, 54, 134-141. https://doi.org/10.1016/j.chb.2015.07.058

Sari, P., Bulantika, S. Z., Utami, F. P., \& Kholidin, F. I. (2020). Pengaruh Manajemen Stress dan Kelola Emosi Terhadap Tingkat Kecemasan Siswa di Masa New Normal. Bulletin of Counseling and Psychotherapy, 2(2), 62-67.

Spinrad, T. L., Losoya, S. H., Eisenberg, N., Fabes, R. A., Shepard, S. A., Cumberland, A., Guthrie, I. K., \& Murphy, B. C. (1999). The relations of parental affect and encouragement to children's moral emotions and behaviour. Journal of Moral Education, 28(3), 323-337. https://doi.org/10.1080/030572499103115

T'ng, S. T., Ho, K. H., \& Low, S. K. (2018). Are you "phubbing" me? The Determinants of Phubbing Behavior and Assessment of Measurement Invariance across Sex Differences. International and Multidisciplinary Journal of Social Sciences, 7(2), 159. https://doi.org/10.17583/rimcis.2018.3318

Thahir, A., Bulantika, S. Z., \& Novita, T. (2021). Gender Differences on COVID-19 Related Anxiety Among Students. Pakistan Journal of Psychological Research, 71-83.

Ugur, N. G., \& Koc, T. (2015). Time for Digital Detox: Misuse of Mobile Technology and Phubbing. Procedia - Social and Behavioral Sciences, 195, 1022-1031. https://doi.org/10.1016/j.sbspro.2015.06.491

Zahavi, D. (2008). Simulation, projection and empathy. Consciousness and Cognition, 17(2), 514-522. https://doi.org/10.1016/j.concog.2008.03.010 
